Sains Malaysiana 49(4)(2020): 871-876

http://dx.doi.org/10.17576/jsm-2020-4904-16

\title{
Enhancement of Non-Ohmic Properties of CoO DopeD ZnO Varistor Ceramics using Soda Lime Silica (SLS) Glass
}

(Peningkatan Sifat Bukan Ohmik Seramik Varistor CoO DopeD ZnO menggunakan Kaca Soda Kapur Silika (SLS))

\author{
Nur Quratul Aini Ismail, Nor Kamilah SA’AT* \& MOHD Hafiz MOHD Zaid
}

\begin{abstract}
$\mathrm{ZnO}$-SLS-CoO (ZSC) based varistor ceramics were prepared at a high sintering temperature of $1100{ }^{\circ} \mathrm{C}$ via the conventional solid-state method. The effect of SLS glass on the electrical properties was studied at the different concentration of SLS glass ranging from 0.5 mol\% to 2 mol\%. Scanning electron microscopy (SEM) and X-ray diffractometer $(X R D)$ were used to examine microstructure and crystal structure of the glass phase based ZSC varistor. For the electrical characteristics, the source measuring unit was used. The result shows that $\mathrm{SiO}$, as the major chemical compound found in the SLS glass that responsible for controlling the $\mathrm{ZnO}$ grain growth. When the concentration of SLS glass higher than $1 \mathrm{~mol} \%$, the dominant peak of $\mathrm{ZnO}$ was found in XRD pattern, which is the primary phase whereas the additional peak belongs to $\mathrm{Zn}_{2} \mathrm{SiO}_{4}$ as the secondary phase. ZSC varistor ceramics with 2 mol\% of SLS glass possessed the best electrical properties with the highest nonlinear coefficient $\alpha$ at 4.38 and the lowest leakage current. The increasing value of a could be due to the increase in oxygen vacancies that eventually contributes to the increase of Schottky barrier formation.
\end{abstract}

Keywords: : Nonlinear coefficient; Schottky barrier; solid-state method; varistors; zinc oxide

\section{ABSTRAK}

Seramik varistor berasaskan $\mathrm{ZnO}$-SLS-CoO (ZSC) disediakan pada suhu pensinteran tinggi $1100{ }^{\circ} \mathrm{C}$ melalui kaedah keadaan pepejal konvensional. Kesan kaca SLS terhadap sifat elektrik dikaji pada kepekatan berbeza kaca SLS antara 0.5 mol\% hingga 2 mol\%. Mikroskopi elektron imbasan (SEM) dan difraktometer sinar-X (XRD) digunakan untuk memeriksa mikrostruktur dan struktur kristal fasa kaca berdasarkan varistor ZSC. Untuk ciri elektrik, unit pengukur sumber telah digunakan. Hasilnya menunjukkan bahawa SiO, adalah sebatian kimia utama yang terdapat di dalam kaca SLS yang bertanggungjawab mengawal pertumbuhan bijirin ZnO. Apabila kepekatan kaca SLS lebih tinggi daripada 1 mol\%, puncak ZnO yang dominan didapati dalam corak XRD, yang merupakan fasa utama manakala puncak tambahan milik $\mathrm{Zn}_{2} \mathrm{SiO}_{4}$ sebagai fasa sekunder. Seramik varistor ZSC dengan 2 mol\% kaca SLS memiliki sifat elektrik terbaik dengan pekali tak linear a tertinggi pada 4.38 dan arus kebocoran terendah. Peningkatan nilai a mungkin disebabkan oleh peningkatan kekosongan oksigen yang akhirnya menyumbang kepada peningkatan pembentukan halangan Schottky.

Kata kunci: Halangan Schottky; kaedah keadaan pepejal; pekali tak linear; varistor; zink oksida

\section{INTRODUCTION}

Varistors are variable resistors, in which the electrical resistivity is changed in the function of the applied voltage. Zinc oxide $(\mathrm{ZnO})$ varistors are polycrystalline ceramic devices with high nonlinear current-voltage (IV) characteristics (Matsuoka 1971). The nonlinearity of current-voltage (I-V) makes the varistor suitable to provide protection to electronic circuits. Commercially, $\mathrm{ZnO}$ varistors are produced by mixing the $\mathrm{ZnO}$ powder with several additives via a conventional solid-state method in different sintering temperature. The microstructure and electrical properties are strongly depending on the processing method and the types of additives (Gilbert \& Freer 2002). Due to the empty lattice sites in the octahedral and tetrahedral crystal lattice of wurtzite structure, the substitution ions or additives are favourable to occupy the vacant sites (Clarke 1999). The types of additives can be classified based on their electrical properties (Clarke 1999; Eda 1989; Gilbert et al. 2000; Matsuoka 1971). For the nonlinearity enhancers, the additives such as Cobalt (Co), Manganese (Mn), Antimony ( $\mathrm{Sb}$ ), and Chromium $(\mathrm{Cr})$ are used. For grain growth retardant, the addictive such as Antimony ( $\mathrm{Sb}$ ) and Silicon ( $\mathrm{Si}$ ) was used (Levinson \& Philipp 1986). The previous research has proved that the glass additives typed varistor enhancer provided an improvement in the thermal stability and $E-J$ characteristic (Chiou et al. 1990; Lin et al. 1993). The majority of the research has developed laboratory scaledglass from the mixture of sand silica. However, this process is time consuming and expensive. 
In this paper, we use the soda-lime-silica (SLS) glass as additives. SLS glass is composed of silicon dioxide $\left(\mathrm{SiO}_{2}\right)$, sodium oxide $\left(\mathrm{Na}_{2} \mathrm{O}\right)$ and calcium oxide $(\mathrm{CaO})$. The incorporation of Si-riched glass-based material enables the improvement of nonlinear coefficient, electrical and thermal stability (Chiou et al. 1990; Lee \& Tseng 1992; Lin et al. 1993). Wu et al. (2010) reported the successfulness of incorporated the element $\mathrm{Si}$ into the $\mathrm{Zn}$ lattice site. It is believed that the eases incorporation of $\mathrm{Si}$ ion into the $\mathrm{ZnO}$ lattice could be attributed to its small ionic radius of $\mathrm{Si}^{4+}$ at $\mathrm{r}=0.26 \AA$ (Bai et al. 2017a). The nonlinear properties of $\mathrm{ZnO}$ varistor being attributed to the presence of unique grain boundaries associated from the defect concentration gradient posing a potential barrier between $\mathrm{ZnO}$ grains through segregation during the liquid phase-sintering process (Lee \& Tseng 1998). As an alternative additive, SLS glass that contains $\mathrm{SiO}_{2}$ can control the $\mathrm{ZnO}$ grain growth which directly affects the varistor voltage and leads to the increase in potential barrier height. This process indirectly improves the nonlinear properties of $\mathrm{ZnO}$ varistor. The $\mathrm{SiO}_{2}$ additive inhibits the $\mathrm{ZnO}$ grain growth which results in an increase in the breakdown voltage while enhances the barrier height as well as the nonlinear coefficient, $\alpha$ (Bai et al. 2017a). However, there is a limited study report on the effect of SLS glass as additives in improving the electrical properties of $\mathrm{ZnO}$ varistor. The majority of recycles SLS glass is targeted used in the optoelectronic application.

Therefore, the aim of this study was to investigate the effect of the microstructure and nonlinear properties of $\mathrm{CoO}_{0.2} \mathrm{ZnO}_{0.8}$ based varistors in different concentration of SLS glass addictive (0.5 to $2 \mathrm{~mol} \%$ ) for its potential used in low voltage application.

\section{MATERIALS AND METHODS}

\section{SAMPLE PREPARATION}

The raw material of (ZSC) varistors composed of (98- $x)$ $\mathrm{mol} \% \mathrm{ZnO}, 2 \mathrm{~mol} \% \mathrm{CoO}$ and $x \mathrm{~mol} \%$ SLS glass where $x$ is the concentration of additive at $0.5,1.0,1.5$, and 2.0 $\mathrm{mol} \%$. The samples were prepared using a conventional solid-state method. Chemical composition of SLS glass waste consists mainly of $70 \%$ silicon dioxide $\left(\mathrm{SiO}_{2}\right), 12 \%$ sodium oxide $\left(\mathrm{Na}_{2} \mathrm{O}\right)$, and $11 \%$ calcium oxide $(\mathrm{CaO})$ (Zaid et al. 2016). To produce a SLS glass powder, SLS waste glass bottle from 'Life brand' was crushed using a stainless steel plunger (Effendy et al. 2017). Then, the SLS glass was ground using a mortar and pestle into a size of $\sim 75 \mu \mathrm{m}$. The detailed compositions of the samples are tabulated in Table 1 . The raw materials $(\mathrm{ZnO}, \mathrm{CoO}$ and SLS glass) powder was mixed by a ball-milling technique using a zirconia ball. In detail, $0.3 \mathrm{~g}$ of sodium metasilicate was mixed in $40 \mathrm{~mL}$ of distilled water and ball milled for $24 \mathrm{~h}$. Then, the slurry was dried at $70{ }^{\circ} \mathrm{C}$ for $12 \mathrm{~h}$ before pre-sintered at a temperature of $800{ }^{\circ} \mathrm{C}$ for $2 \mathrm{~h}$. The $1.75 \mathrm{wt}$. \% of polyvinyl alcohol (PVA) was added as a binder to avoid cracks in the samples and then granulated by sieving through the $75 \mu \mathrm{m}$ mesh screen. The mixture powder samples were pressed into pellets with $10 \mathrm{~mm}$ diameter and $1 \mathrm{~mm}$ in thickness at a pressure of 4 tonnes $/ \mathrm{m}^{2}$. Finally, the pellets were sintered at a temperature of $1100{ }^{\circ} \mathrm{C}$ for $2 \mathrm{~h}$ with heating and cooling rates of $5^{\circ} \mathrm{C} / \mathrm{min}$.

\section{MICROSTRUCTURE ANALYSIS}

The crystalline phase was identified using an X-ray diffractometer (PANalytical X'Pert) with a $\mathrm{Cu} \mathrm{K \alpha}$ radiation $(\lambda=1.540598 \AA$ ). XRD software (X'Pert high score software Pro PW3040/60) was used to analyse the crystalline phases of the samples. The average crystalline size of the samples was determined using the Debye Scherer's equation:

$$
\mathrm{d}=\mathrm{k} \lambda / \beta \cos \theta
$$

where $\mathrm{d}$ is a mean crystalline size of major diffraction peaks; $\mathrm{k}$ is a grain shape-dependent constant (approximate 0.89 ); $\beta$ is full width at half maximum (FWHM) of the diffraction peaks; and $\theta$ is a Bragg reflection peak.

The density $(p)$ of the ZSC sintered samples were measured at room temperature by using an electronic densitometer followed the standard Archimedes principle (Alfa Mirage, Model MD-300S). The density of the sintered samples was then calculated:

$$
p=\mathrm{W}_{\text {air }} p_{\text {diswater }}\left(\mathrm{W}_{\text {air }}-\mathrm{W}_{\text {diswater }}\right)
$$

where $p$ and $p_{\text {diswater }}$ are the density of the samples and distilled water $\left(p_{\text {diswater }}=1.0000 \mathrm{~g} / \mathrm{cm}^{3}\right)$, respectively; $\mathrm{W}_{\text {air }}$ is the weight of the sample in air; and $\mathrm{W}_{\text {diswater }}$ is the weight of the sample immersed in distilled water.

The microstructure and morphology of ceramics were examined by a scanning electron microscope (SEM, model: JEOL 6400) that attached with an energy dispersive X-ray (EDX). The ZSC sintered samples were coated with gold because the material is non-conductive. This process aims to reduce the charging effect during the analysis. The average grain size $(D)$ of the sintered samples is determined with the linear intercept method, given in (3):

$$
D=1.56 \mathrm{~L} / \mathrm{MN}
$$

where $\mathrm{L}$ is the random line length on the micrograph; $\mathrm{M}$ is the magnification of the micrograph; and $\mathrm{N}$ is the number of grain boundaries intercepted by the lines (Wurst et al. 1972).

\section{ELECTRICAL MEASUREMENT}

To measure the electrical properties, the ZSC sintered samples were polished with 1300 -grit silicon carbide paper on both sides. All the ZSC sintered samples are 
coated with silver conductive paint (SCP) and cured at $550{ }^{\circ} \mathrm{C}$ for $10 \mathrm{~min}$. The non-linear coefficient was extracted from a current density $(J)$ - electric field $(E)$ characteristics at room temperature. The analysis was measured using a low voltage source that measured from a Keithley Model-2410 unit. The nonlinear coefficient $(\alpha)$ is calculated from the empirical relation:

$$
J=K E^{\alpha}
$$

where $K$ is a proportion factor and the nonlinear coefficient $(\alpha)$ is determined by

$$
\alpha=\frac{(\log J 2-\log J 1)}{(\log E 2-\log E 1)} \text { (5) }
$$

with $J_{1}=10 \mu \mathrm{A}, J_{2}=100 \mu \mathrm{A}, E_{1}$ and $E_{2}$ are electric fields corresponding to current density $J_{1}$ and $J_{2}$, respectively (Onreabroy et al. 2005). The leakage current density $\left(J_{L}\right)$ was measured at $0.85 E_{10 \mathrm{AA}}$. The breakdown voltage $E_{\mathrm{B}}$ $(\mathrm{V} / \mathrm{cm})$ is calculated from $E=\mathrm{V}_{1 \mu \mathrm{A}} / \mathrm{h}$, where $\mathrm{h}$ is the thickness of the sample.

The non-ohmic properties of ZSC varistor are due to the barrier height effect in the grain boundaries. The potential barrier height $\left(\phi_{B}\right)$ is estimated according to the Schottky current equation:

$$
\mathrm{J}=\mathrm{AT}^{2} \exp \left[\beta \mathrm{E}^{1 / 2}-\phi_{B}\right] / \mathrm{K}_{\mathrm{B}} \mathrm{T}
$$

where $\mathrm{A}$ is the Richardson's constant $\left(30 \mathrm{~A} / \mathrm{cm}^{2} \mathrm{~K}^{2}\right)$; T is the absolute temperature; $\mathrm{E}$ is the electrical field; $\phi_{B}$ is potential barrier height; $\mathrm{K}_{\mathrm{B}}$ is the Boltzmann constant $\left(8.167 \times 10^{-5} \mathrm{eV} / \mathrm{K}\right)$; and $\beta$ is a constant related to the potential barrier width by the relationship constant (Nahm 2013).

\section{RESULTS AND DISCUSSION}

\section{XRD ANALYSIS}

Figure 1 shows the XRD patterns for the sample prepared from different concentrations of SLS glass. The patterns showed a continuous and discrete intense peak, thus, reflecting a high crystalline compound. The majority of the diffraction peaks are indexed to the hexagonal wurtzite $\mathrm{ZnO}$ from the database of (ICSD Ref. No. 98-005-5014). The dominant peaks are detected at $2 \theta$ of $34.4^{\circ}$ along the (l $\left.0 \begin{array}{ll}0 & 2\end{array}\right)$ plane of $\mathrm{ZnO}$ crystal (Bai et al. 2017b; Isa et al. 2018; Meng et al. 2018). There is no secondary peak was detected, indicating the dopant ions $\mathrm{Co}^{2+}$ successfully substitute inside the lattice of $\mathrm{ZnO}$ (Caglar 2013). The favourable incorporation of $\mathrm{Co}^{2+}$ into the vacant sites of wurtzite structure of $\mathrm{ZnO}$ could be attributed to the octahedral void and partially tetrahedral void site in the crystal system (Gupta 1990). The addition of SLS glass promotes the atomic structure rearrangement in the $\mathrm{ZnO}$ matrix. When the concentration of SLS glass increase, it is observed that the XRD peak of $\mathrm{ZnO}$ presented a slight shift to a high diffraction angle which are from $34.487^{\circ}$ to $34.517^{\circ}$ whereas the lattice spacing, $\mathrm{d}$ of the sample was decreased from $2.598 \AA$ to $2.596 \AA$. When the SLS glass content at $1.5 \mathrm{~mol} \%$ and $2.0 \mathrm{~mol} \%$, there is one new peak was emerged at $2 \theta$ of $25.468^{\circ}$ and can be indexed to the (220) plane of $\mathrm{Zn}_{2} \mathrm{SiO}_{4}$. The $\beta$-phase $\mathrm{Zn}_{2} \mathrm{SiO}_{4}$ observed at $700{ }^{\circ} \mathrm{C}$ and transform to $\alpha$-phase $\mathrm{Zn}_{2} \mathrm{SiO}_{4}$ as increasing the temperature to $800{ }^{\circ} \mathrm{C}$ (Rashid et al. 2017). There is no transition of metastable phases was observed in the diffraction pattern of $\mathrm{Zn}_{2} \mathrm{SiO}_{4}$ as high temperature was used at $1100{ }^{\circ} \mathrm{C}$.

\section{SCANNING ELECTRON MICROSCOPY (SEM)}

Figure 2 shows the SEM images of ZSC varistors prepared from different SLS glass concentrations at the sintering temperature of $1100{ }^{\circ} \mathrm{C}$. The micrograph presented a controllable growth of large grains in the sample. When the concentration of SLS increased, the grain growth was decreased. This phenomenon signified the $\mathrm{SiO}_{2}$ act as grain inhibitor in the ZSC varistor ceramics. During the liquid phase sintering process, the segregation of $\mathrm{SiO}_{2}$ filled the pores and voids lattice in $\mathrm{ZnO}$ crystal and eventually lead to the increases of grain boundaries and decreases of grain size. The average grain size of the prepared pellet was calculated. It is noted that the grain size was initially increased from $25.015 \mu \mathrm{m}$ to $31.200 \mu \mathrm{m}$ for the $0.5 \mathrm{~mol} \%$ and $1.0 \mathrm{~mol} \%$ of SLS glass, respectively. These findings could be due to the small content of $\mathrm{SiO}_{2}$ in the sample, leading to inhomogeneous grain growth in the sample. When the concentration of SLS glass further increased to $2 \mathrm{~mol} \%$, the grain size was decreased to $22.464 \mu \mathrm{m}$. This result reflecting the condition of ( $>1$ mols $\%)$ of SLS glass enable the control of the grain growth in ZSC varistor.

Figure 3 shows the result of EDX analysis for the sample prepared at different concentration of SLS glass. For sample with a low concentration of SLS glass $(<1$ $\mathrm{mol} \%$ ), there are only four elements were detected which are $\mathrm{Zn}, \mathrm{O}, \mathrm{Co}$, and $\mathrm{Na}$. The entire sample was originated from the synthesized raw materials. For the SLS glass content more than $1 \mathrm{~mol} \%$, the Si element was detected in the EDX spectra. It is believed that the $\mathrm{Si}$ elements exist at the grain boundaries of the $\mathrm{ZnO}$ sample at the weight percentage of 8.15 and 10.18 for the sample with SLS glass of $1.5 \mathrm{~mol} \%$ and $2.0 \mathrm{~mol} \%$, respectively. This result is in good agreement with the aforementioned claim.

Furthermore, the density of the sample was also determined and the results were tabulated in Table 2 . When the concentration of SLS increased, the density of the ZSC was found increased from 5.043 to $5.368 \mathrm{~g}$ / $\mathrm{cm}^{3}$. This result could be due to the: decrease of porosity that enhances the microstructure properties of the sample, and substitution of $\mathrm{Si}^{4+}$ ion into the pores and the grain boundary of ZSC sample.

\section{ELECTRICAL PROPERTIES}

The electrical properties of the ZSC varistor ceramics 
with different SLS concentration are characterized by the applied current density-electric field $(J-E)$ properties and the results were depicted in Figure 4. The sample containing $2 \mathrm{~mol} \%$ of SLS glass concentration shows the sharpest knee between the pre breakdown and breakdown regions. According to Nahm (2007), the value of the nonlinear coefficient is linearly dependent on the shape of the knee of the curves between the pre breakdown region and breakdown regions. The value of the nonlinear coefficient $(\alpha)$ of the sample was analysed using (5). When the concentration of SLS increased, it is found that the value of $\alpha$ increased from 2.82 to 4.38 . The sample with $2 \mathrm{~mol} \%$ of SLS glass content exhibited the highest nonlinear coefficient, $\alpha$ of 4.38 . The increment of the nonlinear electrical properties of ZSC varistors could be attributed to the Double Schottky Barrier (DSB) phenomenon that relies on the ion migration and oxygen adsorption at grain boundary layers. For this project, it is believed that the ions are easily diffuse into the void lattice in Co-doped $\mathrm{ZnO}$ lattice owing to its small ionic radius $(0.26 \AA)$.

Apart from that, the electrical properties parameters which include the nonlinear coefficient $(\alpha)$, the breakdown field $(E)_{10 \mu \mathrm{A}}$, the leakage current density $\left(J_{\mathrm{L}}\right)$, average grain size $(D)$ and density $(p)$ are also calculated and listed in Table 2. It can be concluded that the $\mathrm{E}_{10 \mu \mathrm{A}}$ of ZSC varistor is strongly depended on the number of grain boundaries between the electrodes. When the concentration of SLS increased, the grain size of the sample decreased. This result in turn increases the grain boundary in the sample and provides a Schottky barrier along the conduction path. This claim was supported by the value of breakdown voltage $\left(E_{10 u \mathrm{~A}}\right)$ as tabulated in Table 2 . The $E_{10 \mu \mathrm{A}}$ increases gradually as the concentration of SLS glass increased which are from $429.087 \mathrm{~V} / \mathrm{cm}$ to $727.068 \mathrm{~V} / \mathrm{cm}$. This result is comparable to others reported varistor doped with silicon dioxide samples, which exhibited a similar shape of characteristics curves and showed lower breakdown voltage in the range of $358.11 \mathrm{~V} / \mathrm{mm}$ to $1080 \mathrm{~V} / \mathrm{mm}$ with the $\mathrm{SiO}_{2}$ content from 0 to 6 wt. \% (Bai et al. 2017a). In addition, the leakage current density, $J_{L}$ of ZSC varistor was also calculated. It was observed that the value decreased from 6.802 $\mu \mathrm{A} / \mathrm{cm}^{2}$ to $4.991 \mu \mathrm{A} / \mathrm{cm}^{2}$, confirming the increase in barrier height. By using (6), the value of the barrier height is determined and found increased from $0.633 \mathrm{eV}$ to $0.869 \mathrm{eV}$. Therefore, $\mathrm{SiO}_{2}$ contain in the SLS glass control grain growth of $\mathrm{ZnO}$ and resulting in increasing breakdown voltage $\left(E_{10 \mu \mathrm{A}}\right)$, decrease in leakage current density $\left(J_{\mathrm{L}}\right)$, increase in nonlinear coefficient $(\alpha)$, and increase in barrier height $\left(\Phi_{\mathrm{B}}\right)$. However, due to the small amount of SLS glass used as additives, the other major component $\mathrm{Na}_{2} \mathrm{O}$ and $\mathrm{CaO}$ cannot be detected.

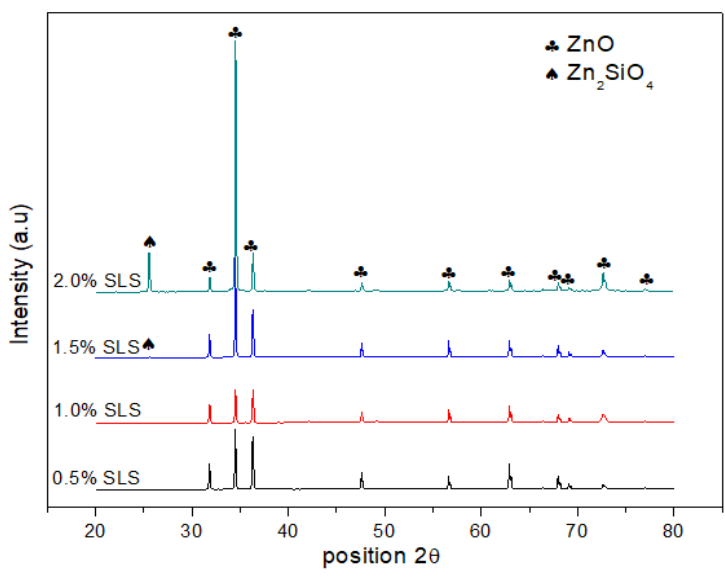

FIGURE 1. XRD pattern of $\mathrm{ZnO}$ varistor at different concentration of SLS glass
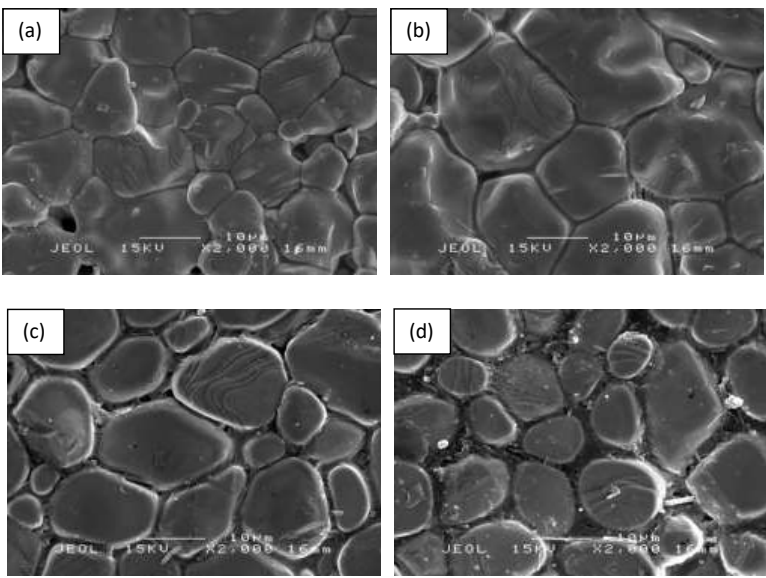

FIGURE 2. SEM micrograph of different SLS glass concentration (a) $0.5 \mathrm{~mol} \%$, (b) $1.0 \mathrm{~mol} \%$, (c) $1.5 \mathrm{~mol} \%$ and (d) $2.0 \mathrm{~mol} \%$ 

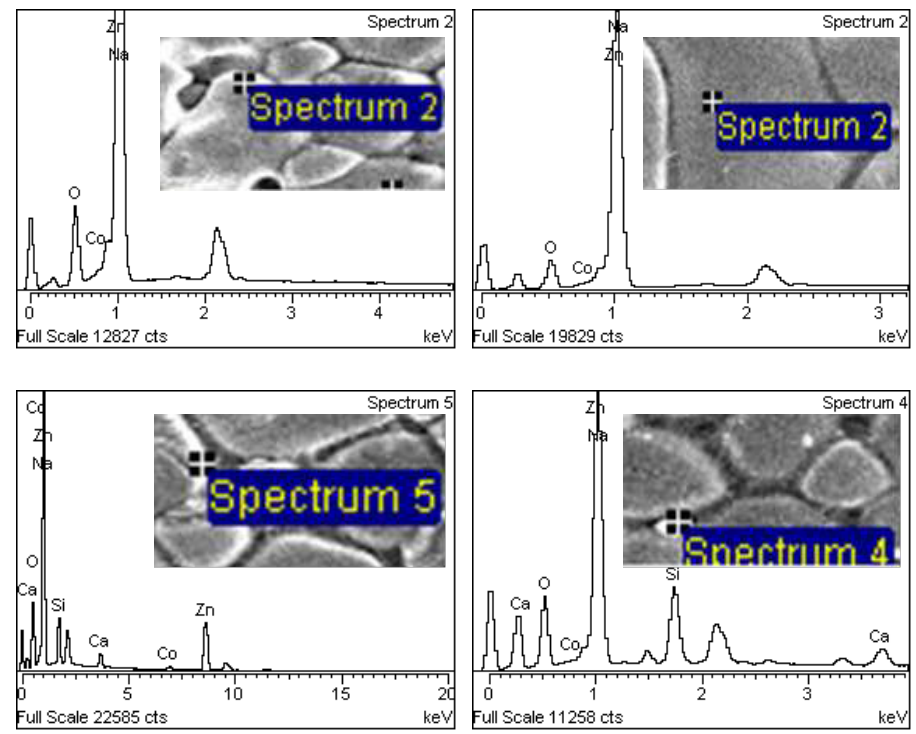

FIGURE 3. SEM attached with EDX of at different concentration of SLS glass

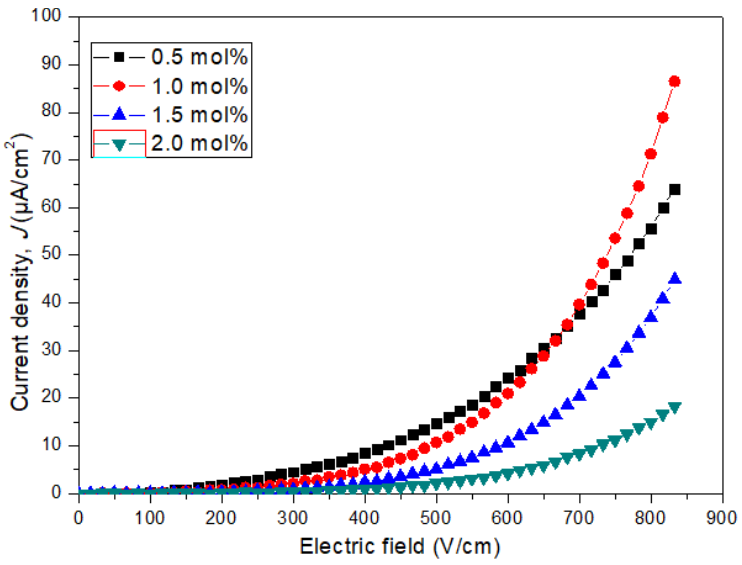

FIGURE 4. J-E curve of SLS glass doped $\mathrm{ZnO}$ based varistor ceramics glass

TABLE 1. Chemical compositions of $\mathrm{ZnO}_{1-\mathrm{x}}-\mathrm{SLS}_{\mathrm{x}}-\mathrm{CoO}_{2}$ based varistor ceramics

\begin{tabular}{ccccc}
\hline Sample $(\mathrm{mol} \%)$ & $\mathrm{ZnO}(\mathrm{g})$ & $\mathrm{SLS}(\mathrm{g})$ & $\mathrm{CoO}(\mathrm{g})$ & Sample powder $(\mathrm{g})$ \\
\hline 0.5 & 19.41 & 0.22 & 0.37 & 20.00 \\
1.0 & 19.20 & 0.43 & 0.37 & 20.00 \\
1.5 & 18.99 & 0.64 & 0.37 & 20.00 \\
2.0 & 18.78 & 0.85 & 0.37 & 20.00 \\
\hline
\end{tabular}

TABLE 2.Density $(p)$, average grain size $(D)$, breakdown electrical field $\left(E_{10 \mu \mathrm{A}}\right)$, nonlinear coefficient $(\alpha)$, and leakage current density $\left(J_{L}\right)$ of ZSC varistor ceramics at different SLS glass concentration

\begin{tabular}{cccccc}
\hline $\begin{array}{c}\text { Sample } \\
(\mathrm{mol} \%)\end{array}$ & $\begin{array}{c}p \\
(g / \mathrm{cm} 3)\end{array}$ & $\begin{array}{c}D \\
(\mu \mathrm{m})\end{array}$ & $\begin{array}{c}E_{10 \mu \mathrm{A}} \\
(\mathrm{V} / \mathrm{cm})\end{array}$ & $\alpha$ & $\begin{array}{c}J_{L} \\
\left(\mu \mathrm{A} / \mathrm{cm}^{2}\right)\end{array}$ \\
\hline 0.5 & 5.043 & 25.015 & 429.087 & 2.822 & 6.802 \\
1.0 & 5.179 & 31.200 & 490.526 & 4.222 & 5.594 \\
1.5 & 5.233 & 24.960 & 591.901 & 4.299 & 5.293 \\
2.0 & 5.368 & 22.464 & 727.068 & 4.384 & 4.991 \\
\hline
\end{tabular}




\section{CONCLUSION}

The ZSC varistor ceramics were fabricated by the conventional solid-state method at the sintering temperature of $1100{ }^{\circ} \mathrm{C}$ in order to improve the electrical properties of varistors. The XRD and SEM analyses proved that element $\mathrm{Si}$ was successfully distributed in the grain boundary and within the grains region. The uses of SLS glass as additives could trigger a new crystal phases of $\mathrm{Zn}_{2} \mathrm{SiO}_{4}$. Besides, $\mathrm{SiO}_{2}$ also acts as a grain inhibitor source by reducing the grain size of $\mathrm{ZnO}$ from $25.015 \mu \mathrm{m}$ to $22.464 \mu \mathrm{m}$ and eventually increases the breakdown voltage from $429.087 \mathrm{~V} / \mathrm{cm}$ to $727.068 \mathrm{~V} /$ $\mathrm{cm}$. The ZSC sintered sample doped with $2 \mathrm{~mol} \%$ SLS glass showed excellent electrical properties with the highest nonlinear coefficient, $\alpha$ of 4.38 .

\section{ACKNOWLEDGEMENTS}

The authors are grateful to the Universiti Putra Malaysia for the financial supporting in this work under the research grant no. GP-IPS/2018/9664200.

\section{REFERENCES}

Bai, H., Li, M., Xu, Z., Chu, R., Hao, J., Li, H. \& Li, G. 2017a. Influence of $\mathrm{SiO}_{2}$ on electrical properties of the highly nonlinear $\mathrm{ZnO}-\mathrm{Bi}_{2} \mathrm{O}_{3}-\mathrm{MnO}_{2}$ varistors. Journal of the European Ceramic Society 37(13): 3965-3971.

Bai, H., Zhang, M., Xu, Z., Chu, R., Hao, J., Li, H. \& Li, G. 2017b. The effect of $\mathrm{SiO}_{2}$ on electrical properties of low temperature-sintered $\mathrm{ZnO}-\mathrm{Bi}_{2} \mathrm{O}_{3}-\mathrm{TiO}_{2}-\mathrm{Co}_{2} \mathrm{O}_{3}-\mathrm{MnO}_{2}$-based ceramics. Journal of the American Ceramic Society 100(3): 1057-1064.

Chiou, B.S., Chen, T.C., Li, J.J. \& Duh, J.G. 1990. Thermal and electrical stability of $\mathrm{ZnO}$ varistors with glass additives. Journal of Electronic Materials 19(12): 1339-1344.

Clarke, D.R. 1999. Varistor ceramics. Journal of the American Ceramic Society 82(3): 485-502.

Caglar, Y. 2013. Sol-gel derived nanostructure undoped and cobalt doped $\mathrm{ZnO}$ : Structural, optical and electrical studies. Journal of Alloys and Compounds 560: 181-188.

Eda, K. 1989. Zinc oxide varistors. IEEE Electrical Insulation Magazine 5(6): 28-30.

Effendy, N., Wahab, Z.A., Abdul Aziz, S.H., Matori, K.A., Zaid, M.H.M. \& Rashid, S.S.A. 2017. Characterization and optical properties of erbium oxide doped ZnO SLS glass for potential optical and optoelectronic materials. Materials Express 7(1): 59-65.

Gilbert, I. \& Freer, R. 2002. Donor and acceptor doping of zinc oxide varistors. Journal of Physics: Condensed Matter 14(4): 945.

Gupta, T.K. 1990. Application of zinc oxide varistors. Journal of the American Ceramic Society 73(7): 1817-1840.

Isa, N.H., Azis, R.S. \& Saat, N.K. 2018. The effect of sintering time on the microstructural and nonlinear electrical properties of $\mathrm{Zn}-\mathrm{V}-\mathrm{Mn}-\mathrm{Nb}-\mathrm{Nd}-\mathrm{O}$ low-voltage varistor ceramics. Journal of Physics: Conference Series. Volume 1083. IOP Publishing.
Levinson, L.M. \& Philipp, H.R. 1986. Zinc oxide varistors - A review. Am. Ceram. Soc. Bull. 65(4): 639-646.

Lin, J.N., Lin, C.M., Kao, C.C. \& Chang, W.C. 1993. Electrical properties and degradation phenomena of glass-doped $\mathrm{ZnO}$ chip varistors. Materials Science and Engineering: B 20(3): 261-265.

Lee, Y.S. \& Tseng, T.Y. 1998. Correlation of grain boundary characteristics with electrical properties in $\mathrm{ZnO}$-glass varistors. Journal of Materials Science: Materials in Electronics 9(1): 65-76.

Lee, Y.S. \& Tseng, T.Y. 1992. Phase identification and electrical properties in $\mathrm{ZnO}$-glass varistors. Journal of the American Ceramic Society 75(6): 1636-1640.

Matsuoka, M. 1971. Nonohmic properties of zinc oxide ceramics. Japanese Journal of Applied Physics 10(6): 736.

Meng, P., Gu, S., Wang, J., Hu, J. \& He, J. 2018. Improving electrical properties of multiple dopant $\mathrm{ZnO}$ varistor by doping with indium and gallium. Ceramics International 44(1): 1168-1171.

Nahm, C.W. 2013. Low-temperature sintering effect on varistor properties of $\mathrm{ZnO}-\mathrm{V}_{2} \mathrm{O}_{5}-\mathrm{MnO}_{2}-\mathrm{Nb}_{2} \mathrm{O}_{5}-\mathrm{Bi}_{2} \mathrm{O}_{3}$ ceramics. Ceramics International 39(2): 2117-2121.

Nahm, C.W. 2007. The effect of sintering temperature on electrical properties and accelerated aging behavior of PCCL-doped $\mathrm{ZnO}$ varistors. Materials Science and Engineering: B 136(2-3): 134-139.

Onreabroy, W., Tunkasiri, T. \& Sirikulrat, N. 2005. Effects of alumina surrounding in sintering process on $\mathrm{ZnO}-\mathrm{Bi}_{2} \mathrm{O}_{3}$ varistors doped with CoO. Materials Letters 59(2-3): 283 288

Rashid, S.S.A., Ab Aziz, S.H., Matori, K.A., Zaid, M.H.M. \& Mohamed, N. 2017. Comprehensive study on effect of sintering temperature on the physical, structural and optical properties of Er3+ doped ZnO-GSLS glasses. Results in Physics 7: 2224-2231.

Wu, Z.H., Fang. J.H., Xu, D., Zhong, Q.D. \& Shi, L.Y. 2010. Effect of $\mathrm{SiO}_{2}$ addition on the microstructure and electrical properties of ZnO-based varistors. International Journal of Minerals, Metallurgy and Materials 17(1): 86-91.

Wurst, J.C. \& Nelson, J.A. 1972. Lineal intercept technique for measuring grain size in two-phase polycrystalline ceramics. Journal of the American Ceramic Society 55(2): 109-109.

Zaid, M., Hafiz, M., Amin Matori, K., Abdul Aziz, S.H., Kamari, H.M., Yunus, M. \& Samsudin, N.F. 2016. Fabrication and crystallization of ZnO-SLS glass derived willemite glassceramics as a potential material for optics applications. Journal of Spectroscopy 14: 1-7.

Department of Physics

Faculty of Science

Universiti Putra Malaysia

43400 UPM Serdang, Selangor Darul Ehsan

Malaysia

*Corresponding author; email: kamilah@upm.edu.my

Received: 9 October 2019

Accepted: 2 January 2020 